\title{
Changing metaphorical constructs in the writing of Jack Mapanje.
}

\section{Alison McFarlane}

Jack Mapanje joins the chorus of African writers whose collective voice is one of dissent and exposure. The very act of writing represents a courageous statement of their belief in the right to express themselves in a public forum; they challenge the political regimes controlling their cultures. But, by writing in English, is Mapanje contributing to the demise of his own culture or does his changing metaphorical structure reflect the demands that social history and politics impose upon any poet?

One of Mapanje's objectives was to sustain the oral voice through the medium of the written English language without violating its integrity. By adopting the formalised version of Western literature, Mapanje consequently accepts its incumbent ideologies and its confinement of metaphor implicit in the process of writing. To salvage the original voice 'where masters talked with bows', was to assume the voice of the dissenter. But, as Mapanje discovered, a true voice becomes a censored voice: when a neotraditional authority could be undermined by a traditional aesthetic, censorship boards were set up to protect the leadership against truth. Indeed, the Malawi in which Mapanje started writing was a country scoured by corruption which permeated every aspect of life.

The challenge for Mapanje was to subvert this system without producing politically controversial works or, conversely, works only decodable to the literary coterie. As Mapanje, himself, writes: 'The role of African writers today is to preserve through metaphors their cultural heritage which must be a fusion of their ancestral culture and that of the rest of the world to which they have been exposed by their British education...'2 Jack Mapanje, Felix Mnthali, Frank Chipasula and David Rubadiri, fought to protect their cultural heritage while recognising the contribution of foreign cultural forces.

In Mapanje's first volume of poetry, Of Chameleons and Gods, there is a nostalgic yearning for the immutability of traditional myths and metaphors. This is contradicted by the inevitability of political and social change which necessitates parallel changes in poetry. Malawian culture is founded on archetypal metaphors, many of which are 
commonly found in the oral traditions of sub-Saharan Africa. In their primary and secondary forms they provide stable and accessible belief systems which are disrupted by the invasion of diverse religious and economic credos. The elephant, for example, is recognised throughout Africa as the guardian of heritage and dignity. No greater accolade could be afforded to an African leader (such as Jomo Kenyatta of Kenya) than being entitled mzee, the wise old elephant ${ }^{3}$. Only the omniscience of the archetype allows it to be channelled into secondary forms of metaphor: the elephant's bones and burial ground become mystical embodiments of the permanence of heritage; the use of elephant masks in ceremony and dance embody man's attempt to absorb the honour and mystique of the animal. This complex archetypal structure provides the vocabulary of the oral tradition and thus reflects the role of that tradition in preserving origin, heritage and freedom.

\section{bila asili utumwa}

(one who knows not one's origin is doomed to servitude) ${ }^{4}$

By maintaining affiliation with metaphor, rather than simile, Mapanje evokes the security which this stability offers; however by using the metaphors in a way that exposes their changing nature he reveals the limitations of this archetype. The use of vigorous metaphor in Of Chameleons and Gods would suggest that Mapanje was not fully aware of the extent to which his figurative connotations could change. As his work develops, it becomes evident that ambiguities do not stand solely for the confusions of conflicting cultures but can be solidified as signifiers of cultural coalescence. Skipping Without Ropes (1998), uses the ambiguity of metaphor with a greater poetic self-consciousness. Mapanje is no longer chauvinistically defending the devices of the oral tradition and condemning its perversion; he has now assumed a writing practice which brings with it a 'writerly' self-consciousness. This transition was accelerated by his incarceration and subsequent exile, documented in his second volume, The Chattering Wagtails of Mikuyu Prison (1993). If a writer is under threat he cannot but make the transition part of his subject matter; by accepting the contradictions implicit in the selfimposed task of being a writer, Mapanje makes the transition from curator of the oral tradition to a collocational ironist ${ }^{5}$ writing in a modern milieu. Thus this transition has to be one of his pre-eminent themes.

This metamorphosis necessitates the use of a more cosmopolitan range of poetic devices. The code of metaphor used to communicate with fellow African artists is a surface code, manifesting itself in specific, isolated metaphors, recapitulated throughout the course of Mapanje's oeuvre. As Wilentz writes: 'if the ordinary meaning of a word is at odds with the context, we tend to seek relevant features of the word and the situ- 
ation that will reveal the intended meaning... ${ }^{6}$. The changing configuration of the code is the indicator that Mapanje refutes any simple resolution between the traditional Malawian and the Western: the fusion of the two hemispheres into one metaphor becomes a metonym for the increasing Western encroachment into Malawian culture.

The title, Of Chameleons and Gods, summarises all the implied paradoxes of cultural cross-pollination. The chameleon is the creature of change, able to adapt to the conditions of its environment through the subterfuge of camouflage. The gods of the traditional Malawian religious outlook are implacable; if it is believed that their being is already all-embracing then they would have no need to change:" 'The animal world occupies it's (sic) undisputed arc in the cycle of existence, subjected to human needs, but nonetheless accorded it's (sic) distinct personalities.'

The first poem, 'Kabula Curio-Shop', ensures that the reader is made instantly aware of the putrefaction generated by the newly introduced mentality. A 'curio shop' is not a national, native symbol, but a product of Western expectations. The act of creating curios relies on an outpouring of energy.

Black wood between carefully bowed legs

the eyes red over bellows and smoke

the sharpening of axes, adzes, carvers.

Man is fused with his raw material because his entity is compressed into two syllabically identical metonyms, 'bowed legs' and 'eyes red'. The physical pain of strained muscles is echoed in the grating cadence of 'axes, adzes, carvers'. The staccato 'ax' sound, the repetition of the sibilant ' $s$ ' and the harsh consonants ' $c$ ' and ' $v$ ' of 'carvers' presents the reader with a cacophony which, on a purely auditory level, evokes the sounds of the workshop. The rhythm, alliteration and assonance of the repeated gerunds becomes the rhythm of the act of sculpting:

the chopping, the whittling and such carving such scooping and scooping then the sand papering and the smoothing.

The second stanza dispenses with the metrical hypnosis as the exigencies of the sculptor are bargained away for a pittance: 'such energy release and the price/bargained away...'. Tourism and materialism violate the sculpture and all the ramifications of its creation. Mapanje questions: 
...would you imagine

now a broken symbol thrown careless

in the nook of a curio-shop: a lioness

broken legs, broken neck, broken udder?

The art of sculpting has been diminished by tourism and degraded by the debased value placed upon it.

In many of the poems we find metaphors recapitulated in changing constructs. Mapanje is establishing a vocabulary which becomes familiar to the reader although it is subject to increasing diversity of interpretation. In 'Song of Chickens', commercial tourism, epitomised by the 'broken symbol' in 'Kabula Curio-Shop', becomes a metaphor for the invasion of Western capitalism which corrupted Malawi's economic and political systems.

The first stanza states a tribal tradition: 'Master, you talked with bows, / Arrows and catapults once'. The second stanza brutalises the first with its sardonic questioning: 'Why do you talk with knives now.../ Is it to impress your visitors?' Under the rules of behaviour the Malawian must extend hospitality to his foreign 'visitors', but in order to do so he has to slaughter the chicken he would previously have protected. Tourism has violated the honour of hospitality. The speaker is forced to concede that the oral voice has been desecrated by Western forces. For Mapanje, this is the defeat of the metaphor; it no longer has validity if the image on which it is based can be thus easily transmuted.

'A Marching Litany to Our Martyrs (3 March 1971)' expounds the ramifications of this enforced capitalism which is now compounded by a dictatorship mired in corruption, be it economic, moral, political or cultural. The corruption is realised in Mapanje's inversion of form and content. The litany, 'an appointed form of public prayer, usually of a penitential character..." is used to satirise what was traditionally an act of honour in the same way that dishonest politicians made a mockery of honest heroics. The Malawian people tried to support their Mozambiquan neighbours. However, this 'heroic' attempt was futile because international powers were haggling for control of the region. This wastage of life is lamented by the incredulous questioning of the poetic voice.

In the name of our dear brothers dead Are we really marching to these tin-drums

Rattling the skeleton beat of heroic

Bones long laid asleep? 
The lexical order of 'dear brothers dead' transforms 'dead' from a normal passive adjective into a paradoxically active past participle which thuds at the end of the iambic line. The potency of the African drum metaphor is diminished; the drums are only 'tin' and their musicality is replaced by the hollow 'rattling' of a 'skeleton beat'. Mapanje's treatment of the refrain, which should be sung by a congregation, juxtaposes the lyrical implications of traditional ballad form against a frank account of the atrocities suffered.

The poem evolves technically out of an anti-collocation, which is discernible within the lexical conjoining of words that juxtapose African and Western images: 'synthetic calabashes of chibuku/Beer...' 'Synthetic' portrays the encroachment of Westernised mediocrity; a calabash is a kind 'of gourd whose shell serves for holding liquid' 10 (probably local traditional beer). The synthetic calabash, made of plastic or tin, is now used to hold Chibuku, a commercially produced beer, brewed over a fermenting machine. The beer was contaminated by chemicals given off by the heated plastic or tin. Ill-advised as to the health risks induced by the chemically infected chibuku, the Malawians would imbibe the 'Beer which numbs their brain'. 'In the name of our growing bellies' extends lexical anti-collocation. For Western civilisation this image connotes an epicurean lifestyle but Mapanje ridicules this affluence by using the image to connote the reverse of plenitude, the distended belly of the starved child.

Each stanza posits a question and reveals disbelief; each word stands as a metonym for the squalor and suffering. 'Rotten weevils' literally account for the 'distended belly', but metaphorically symbolise the shards of culture lamented in so many of Mapanje's poems. The poem ends having descended from spirituality to gross carnality.

Let us revel in parades, lowering the emblem

Of the precious bones long laid asleep.

'Lowering the emblem' is also semantically ambiguous: its literal meaning is the hauling down of the flag at the end of a ceremony, prayer or even poem. But, more significantly, it stresses the diminishing value placed on 'the precious bones' which symbolise all that is sacrosanct about legend, myth and tradition. Perhaps the emblem is lowered at the moment Mapanje puts pen to paper: the act of writing provides a medium for unleashing a controlled anger. The emblem is able to be lowered because the poet seeks no personal exculpation; any attempt to glorify the long dead is now merely a parade for its own sake. 
Militarised parade has replaced spontaneous celebration. In appropriating national culture for political ends, Banda has reduced his people to robotic caricatures of themselves.'The New Platform Dances' again uses the technique of rhetorical questioning to address the 'cheating abstract' of the present dance.

Now, when I see my daughters writhe

Under cheating abstract

Voices of slack drums, ululate

To babble-idea-men-masks

The dance carries no cultural significance; the song has been perverted into empty eulogy. The traditional dances such as chiwoda, chimtali, masewe and jira were "watered down" by Banda: the mbumba were forced to perform these dances for "His Excellency, the Life President, Ngwazi Dr. H. Kamuzu Banda (Ngwazi is a praise name from Ngoni praise poetry; it means 'conqueror') ${ }^{12}$ No.1' in order to fulfil their role in the accepted system of guardianship referred to as unkhoswe. Thus we understand why the speaker questions: 'Why don't I stand up / To show them how we danced...?' The poem closes with the speaker's self castigation; under the dictatorship he is not allowed a voice, a dance or a role:

\author{
Why do I sit still \\ Why does my speech choke. \\ Like I have not danced \\ Before? Haven't I \\ Danced the bigger dance? \\ Haven't I?
}

He should have become a spokesman for the old generation which is denied the right to show the young generation another way of dancing. But even his voice has been muzzled. The costume of dance has become a mockery of proud tradition. The mandated garb for women dancers was the wrapper (chitenje) made from imported Dutch Java cloth, overprinted with Banda's portrait. The obscenity of this form of propagan$\mathrm{da}$, violating all notions of the very decency and modesty that Banda was supposedly advocating, was matched only by the artificial materialistic value of the highly prized and exorbitantly priced wrappers. Mapanje carries forward the changing significance of this metaphor and consolidates its paradox in Chitenje for a Life Time Wedding Cheer' (Skipping Without Ropes). 
In attempting to assume deific status, Banda is shown to have mutated himself into a scavenger who lives off the spoiled 'shards' of his people. There is an ironical but irrefutable logic in Mapanje's use of creation myths to expose this self-delusion. The four-part sequence 'If Chiuta Were Man', employs metaphor to invoke the oral legacy of creation myth but uses it to elucidate the realities of death and destruction. In this poem the reader is challenged by a complexity of metaphor which frequently degenerates into confusion and internal contradiction. Part I, 'The Soft Landing', captures the reverie of a prelapsarian world. By Part II, 'The First Fire', man has become an inventor who devours the natural world. A further shift in the application of the metaphor in Part III returns Chiuta to his rightful place in the heavens. Chiuta's ascension leaves Mankind to be forever reminded of his presumption by living unredeemed in the world which is now his creation. The chameleon is also saved when his ability to change provides him with the skill necessary to escape the ravages of conflagration.

The above synopsis suggests the translation of the metaphor at its most simplistic. It is in Mapanje's poetic diction that we discover the complexity.

Meanwhile hold on woman

Let's glide and glide

On our pioneer project:

Hope is our only hope (Part I)

The mellifluous cadence of 'Let's glide and glide' uses the auditory quality of the words to construct the apotheosis of a mythical world. However, within the cadence and the strophic reliability of the text are harboured cynicism and irony. The 'pioneer project' is perhaps an allegorical reference to Banda's dogmatic pursuit of his own autocratic reforms. The previously hinted irony 'hope is our only hope' unwittingly mocks the so-called utopian ideology.

Creation is dependent upon fertility. Part II invokes the myth of fertility in which Man is born out of the first fire. Fertility becomes sterility when the 'flames' become 'corrosive'. Chiuta's abode is destroyed by his own creation: Man. In Part III the narrator addresses the

fleeing Chiuta:

When you disgruntled spiralled

On spider's frail thread

Swearing you'd see us die feeling

The pain of our own invention, 
The languid rhythm belies the ferocity of the scene. The 'spider's frail thread' extends the metaphor into the suggestion of a conceit; the reader already knows that this "frail thread' has born the weight of God. The non-Christian origin of Chiuta in this creation myth is identified through his lack of compassion and promise of vengeance delivered in the form of a curse. Mapanje's retrospective cry 'Why didn't you also warn / Our eyes would forever be smokey?' echoes the Yao myth of the 'Chameleon and the First Man and Woman': 'When safely above the fire God said 'When those human beings die let them come up here... ${ }^{13}$ Chiuta becomes God when removal from the realms of earth deprives him of omniscience and omnipresence.

The final section, 'So God Became a Chameleon', reveals that myth is replaced when Chiuta gives way to God. The power of myth is replaced by the exigencies of Man and the result is a mutant version of the anthropomorphic force of Chiuta which can take many forms, none of which comprise the absolute which was Chiuta.
A muezzin
With gelded
tongue
slunk in
celibacy
A politician
empiric
muffing
easy balls
fearing fear

God appears as a muezzin, yet the muezzin's tongue is 'gelded'. The fecundity of Chiuta has been replaced by the celibacy of God. The auditory cadence of 'gelded' works as a pun on 'gilded', an apposite description of the fake rhetoric preached by a so-called God. In the second stanza, God is depicted as a 'politician empiric', devoid of moral substance and expedient in all things. God's third persona is highly ironic; the ridiculous notion of God as a football player 'muffing easy balls' is implied and not qualified. If Chiuta becomes God and the gods become chameleons then Banda's adoption of the role of God is more palatable because God is meaningless. If we can humanise God to this extent then we can mutate anything.

The corruption of animist beliefs by incoming religions, notably Christianity and Islam, provides a key to one of the many conflicts confronting twentieth century African writ- 
ers. In 'On African Writing (1971)', Mapanje uses a pivotal metaphor to expose what he deems to be the truth behind the work of writers such as Achebe and Soyinka. Rites of passage are inverted: the rites become more important than the passages they are meant to celebrate.

You've rocked at many passage rites, at drums

Mothers clapping their admiration of your

Initiation voices - now praises of decay

That still memorise some;

The rites of initiation have become commercial ceremonies; 'praises of decay' which follow the appurtenances of ceremony but are devoid of nobility and thus dissolve to form part of the lost myth lamented in the previous poem. Mapanje encourages the reader to transfer this metaphor onto the loss of integrity suffered by writers who traded their heritage for European recognition: 'In your masks you have sung on one praise/After another'. Mapanje's lexicon sharpens in his insinuation that somewhere in the heart of these writers lingers the need to become a man.

...You have sung mouth-songs!

Men struggling to justify what you touched

Only, heard merely! Empty men! Do you realise

You are still singing initiation tunes?

Mapanje condemns these writers for paying mere lip service to their cultural heritage. He attacks the hiatus between form and focus yet his polemic is subject to a weakened form of the paradox endorsed by the writers he is rebuking. These writers tried to focus attention on African writing to the extent that they risked out-striving their own culture and truth.

You've sung many songs, some superb

But these lip-songs are most despicable!

Mapanje concedes their technical prowess, 'some superb', but he condemns their quest for international prestige.

Why do you always suppose mothers

Never want to see you at the conferences

They are for ever hearing about? 
However, Mapanje himse ${ }^{I f}$. as the recipient of such prestige and although it was not able to protect him from censorship and imprisonment, it was initially gained because of his ability to couch the truths of Malawi in the English language. In what ways does Mapanje differentiate between his own writing and that of his literary predecessors? If there is no obvious answer, then reader and critic must concede that Mapanje is a recipient of his own indictment. Mapanje has frequently repeated the metaphor of the 'synthetic calabash' and yet lines 13-15 of this poem vitriolically indict these writers' casting of aspersion on colonial influences; he insinuates that they will never proceed through initiation

...until you've

Stopped all this nonsense about drinking

Palm wine from plastic tumblers!

Mapanje compounds the condemnation through the claim that these writers underestimate the understanding of their own mothers (literal and figurative).

Why do you imagine they never understand

Things? They too can be alert to all this

Absurdity about what you think they think!

Mapanje's implication is that poets should not consider themselves educators; yet his own role as an exponent of tradition and of the vagaries of politics is precisely that of an educator.

By the close of Of Chameleons and Gods Mapanje has admitted his naivete. Returning to the first poem of this volume,'Kabula Curio-Shop', we realise that Mapanje cannot be the sculptor of metaphors and symbols without simultaneously being the broker: he is brokering his written word for a voice. The only way he can broker his integrity is by accepting the formulae that the West has imposed upon him. To ensure that his word will be heard he must accept the economic demands of a publishing industry. Given the expediency of time, which changes the fundamental nature of the 'voice', Mapanje cannot fully recapture the oral tradition of poetry.

The final section of Of Chameleons and Gods is titled'Assembling Another Voice'. Up until this point Mapanje had been abstemious in his condemnation, but the death of Steve Biko (1977) instigates a hardened voice which, resigned to the fact that it cannot recapture the oral character of the past, is determined to be brutally honest in its expo- 
sure of the truth:

The Boers have poked another

Human's sparkling eyes

With electric tongs

Soldering his sharp brain to metal. ${ }^{14}$

It is surprising to see the cliché 'sparkling eyes' used to describe an act of gross barbarity. Mapanje has learned how to employ the devices of English verse against itself; the sardonic 'sparkling eyes', redolent of Victorian sentimentality, jars with the late twentieth century 'electric tongs', the tools of apartheid. The poetic devices are vested in fact. Steve Biko, one of the foremost objectors in the cadre of South African writers and a founder of the Black Consciousness Movement, was, like his politician compatriots, incarcerated, tortured and ultimately killed in police custody by white South Africans who believed in the divine order of apartheid. In Malawi, Banda supported and accepted assistance from the apartheid government of South Africa. ${ }^{15}$ When he made dissent a sacking offence and when the policy of abitrary dismissal became a policy of incarceration, the result was the intellectual castration of those few remaining dissenters. Mapanje was one of these.

As John Dubbey (then Vice Chancellor of the University of Malawi) has indicated, the university was given no licence to intercede on Mapanje's behalf when he was unceremoniously detained, without charge or trial, in September 1987. The silencing of Mapanje was the natural outcome of the sequence of events that had commenced with the banning and destruction of all copies of Of Chameleons and Gods: 'The special Branch had bought all the fifty copies of the book left in the Malawi University Book shop and thrown the copies into pit latrines. ${ }^{16}$ The image of the pit latrine recurs throughout Mapanje's work as the abyss where evidence of barbarity could be deposited: 'Must we surrender to the sallow faces which / Consigned these brittle bones to the reeking / Pit we happily left behind?' ${ }^{\prime 7}$

'On Banning Of Chameleons and Gods (June,1985)', in Mapanje's next volume, The Chattering Wagtails of Mikuyu Prison, is his commentary on this event. By positing the phrase 'senile chameleons' within the context of the questions which surround it, Mapanje examines all that has come to him through the oral tradition. He questions why he should be condemned for his writing when, at a whim, Banda could murder and accidentalize:

...why should my poking at wounds matter more 
Than your hacking at people's innocent necks?

Mapanje admits he cannot recreate the world that was embodied in the oral tradition:

...for children's sake, unchain these truths;

Release the verse you've locked in our hearts!

He succinctly combines the two primary concerns of his own work; whilst reviling the political regime, he simultaneously challenges the established poetic order.

'Your chameleons poke at the raw wounds of

Our nation!' won't rhyme however much you

Try.

This exculpation questions the validity of traditional motifs, alludes to the continuing decimation and corruption of Malawi and mocks the attempt to Europeanise Malawian culture. This is represented by the implied desire to create a rhyming pattern where no such artificial device can ever apply. But as Mapanje has already declared, 'Without kings and warriors occasional verse fails. ${ }^{18}$ The 'kings and warriors' harness the intransigence of the oral voice by controlling it in written form. This was necessary to decodify not only the traditional symbols but also the mutations of these symbols which the newly established traditions of print and profit were to exploit.

In Mikuyu Prison Mapanje's dissenting voice was refined into the voice for which ideology no longer offered exemption or release. He inverts the traditional oral motif which depicts the wagtail as God's envoy to Man: '...the wagtail always warns men when... dangerous creatures are in the neighbourhood. ${ }^{19}$ But in Mapanje's mutation the wagtails become the harbingers of disaster which people outside the prison have not recognised. They are incapable of understanding the reality.

...Don't laugh,

When the day locks up, wagtails

Twitter another tail; you won't laugh

When this courtyard wire gauze fills with

Thousands of wagtails ...

...fabricating their stinking

Shit on the courtyard below for us to mop ... 
The unusual choice of the word 'fabricating' articulates this malignant manufacture, as opposed to the natural function, of defecation. The use of alliteration 'Twitter another tale' is an auditory pun on 'telling tales'. This creates a double irony. These are not the tales of the oral storyteller but the whisper of the police informant. In recounting the treachery of the informant which betrays the purity of the storyteller's vocabulary Mapanje reverts to the integrity of that same storyteller; the use of imperatives allows him to assume the voice of the Elder, the storyteller and the executor of tradition.

Mapanje is lamenting the demystification of myth and symbol and with that the spiritual death of those people whose lives were controlled by the mythology which has been annihilated. Circumcision, 'That annexe writ large they'd christened / Mikuyu Prison where we circumcise you today;' ${ }^{20}$ (italics mine), perhaps becomes a synonym for castration and thus a 'flippant blasphemy'. The blasphemy arises when a rite of passage to manhood becomes a desecration of manhood.

Symbols of fertility and infertility are referred to repeatedly in Mapanje's work. In 'Chitenje for a Lifetime Wedding Cheer' the 'hoe' becomes yet another disenfranchised indigenous symbol: 'for hoes are signs'. The chitenje has already been alluded to in the earlier poem, 'The New Platform Dances', where it is debased as an artefact of Banda's self-aggrandisement. It now reappears to invoke the restored image of the cloth as a citation of joyful celebration. But here in his post-imprisonment, release and exile, Mapanje concedes that the chitenje has been too fundamentally sullied to ever again act as either metaphor or motif. These 'hoes are signs \& chitenjes mere / Covers-'.

Mapanje is notating the erosion of an 'accepted Malawian belief system'; he reinvents the shorthand allusions which once contained the whole body of Malawian cultural integrity as bequeathed by familial ancestors before their own disillusionment.

...After that constant care

Mother, I expected you to show me the rites...

...You gave up too early, mother: two

More months, and I'd have told you the story ${ }^{21}$

This is Mapanje's 'strange requiem'; he mourns all that has been lost and that which has been allowed to manipulate and distort the very tradition it once stood for. Thus we have 'the tattered Catholic choir', the 'lone prayer' and the invention of 'my own cleansing rites'. There must be ritual; if it cannot be sustained then it must be recreated. Mapanje's poetry stands in testament to an oral tradition which, though no longer 
sustainable, can be replicated.

Mapanje is aware of the hiatus between the oral timbre and its content: the sound of literature does not necessarily replicate its sense when that same literature is transmogrified. The use of alliteration, the equalised stanzaic length and the recurrent use of the declamatory ('You gave up too early') are all characteristic of dialogue.

There is no didacticism in this poem; there is interchange and exchange yet we are never privy to answers which are only 'dead roots to lean on'. Mapanje's mother (synonymous with the 'mother figure' of Of Chameleons and Gods) embodies the virtues, values and mystique of his cultural tradition but she 'gave up', taking the fables with her. Thus Mapanje has to invent his own 'cleansing rites'; he has been let down by tradition, myth and the 'tattered' Catholicism which was meant to replace it. He can no longer subscribe to simple mythology, but reworks it so that it is redolent in present reality. The 'umbilical cordage' has been severed and the link to the oral past has been cauterised; on migrating into the safety of a beckoning Western culture Mapanje becomes the viper 'who minutes his own twitches' ${ }^{\prime 2}$. His own mother's reality reveals the anachronistic quality of the oral tradition into which she, and her son, were initiated: 'When did your warm heart go / Cold...' ${ }^{23}$. But in the pseudo-culture that now prevails, anachronism is at best humorous and at worst self-condemnatory.

Although The Chattering Wagtails of Mikuyu Prison was not published until after Mapanje's release from incarceration, its content and voice are the product of his prison experiences. Denied the opportunity to record these poems, whilst in Mikuyu, Mapanje nevertheless composed them and held them in mind and memory until they could be committed to print. Fortuitously, this process had elements in common with the compositional method of the oral praise singers and narrators. The timbre of the oral voice and its reliance upon instantly recognisable archetypes and motifs was as much a product of mnemonic necessity as it was of creative ability.

......and if

Your naked belly should droop \& you feel the stench

Of yesterbooze, why blame God for abandoning you in

Thes: walls named after figs? ${ }^{24}$

These impressions are committed to memory through sensory stimuli: 'naked belly' can he preserved as a photographic image; to 'feel the stench' is an example of synaes- 
thesia where smell and touch are merged and the neologism 'yesterbooze' epitomises the rancid taste that permeates the mouth. This heightened sensory awareness is a distinct feature of the oral tradition; by alerting the listener's sensory reactions the storyteller makes them players in his performance. Indeed, 'the storyteller's calling was a sacred art - the power of narrating was closely linked to magic.' (anon) ${ }^{25}$ It was part of this 'magic' that although the story or song remains familiar through each performance, the immediacy of the imagery allows for a constantly changing, personalised interpretation.

Mapanje's third volume of poetry, Skipping Without Ropes, acknowledges a 'hardening into a set form'26: increasingly the style and structure of the poems represent a hybrid of the oral and written tradition. The previous volumes show us Mapanje as a writer of African literature, intent on preserving the integrity of the oral tradition; Skipping Without Ropes reveals Mapanje as an African writer who was able to fuse the Malawian and the European in order to enrich his own narrative voice. Indeed we question, is this the voice of the 'fourth world' ?27

Skipping Without Rope manifests a formalised structure; its visual configuration is one of regular stanzas, reminiscent of the ballad. But the erratic metrical development and the deceptions of implied rhyme suggest the anonymous force which is the underlying energy of the poet's mocking voice.

Watch, watch me skip without your

Rope watch me skip with my hope

A-one, a-two, a-three, a-four, a-five

I will, a-seven, I do, will skip, a-ten,

The phrase 'skipping without rope' is, on its first level of meaning, simplistic; it refers to the act of taking exercise in prison where one is not even allowed a skipping rope. But the withdrawal of the rope indicates the real concern of the prison establishment. not the denial of exercise, but the sadistic denial of the right to suicide.

I will skip without

Your rope as you say even the lace

I want will hang my neck until I die...

The deception behind the policy is further elucidated: 
You insist I do not require to stretch

My limbs fixed by these fevers of your

Reeking sweat..

Mapanje is no longer allowed to live healthily or die peacefully. It is only the stridency of his voice that suggests the acceptance of Westernised rules of allusion. Where oral recital depended on instinctive and automatic comprehension of mythological symbols, Mapanje now utilises the ambivalence of the extended metaphor. The third level of meaning is revealed in the simple transition of one word; 'without' becomes 'within'.

.. I will skip without, will skip

Within and skip I do without your

Rope...

A people deadened by mental inactivity dictated by a prevailing despot will still find ways to skip 'without rope'. The 'rope' becomes the 'hope'. It is no longer the tool of torture or the binding leash; it is instead the activator of both mental and physical agility. Mapanje's experimentation with literary form is in itself a 'skipping without rope'; he can 'go through the moves' without the assistance of the ordinarily ascribed devices. The diversity of this symbol designates the metamorphosis of Mapanje's poetic psyche; in his work he has begun to assimilate the technocratics of European writing. To deny the validity of European forms would be to alienate himself from a European readership; he would be incarcerating the voice of Africa in the same way that his own African voice was incarcerated ${ }^{28}$

The threat of anonymity and removal from the concourse of academic interchange has solidified, for Mapanje, the necessity of common language. Denied the opportunity to communicate, his understanding of the rules of communication expands to allow for the annihilation of barriers. In this sense Mapanje exemplifies the premise that a writer under threat will make the transition from an arbiter of tradition to a legislator of change.

Once released from Mikuyu, Mapanje was destined for another form of punishment which catalysed his metamorphosis into a self-conscious writerly poet. The strength that had sustained him at Mikuyu was replaced by his guilt about the ongoing torments of his compatriots whilst he had the comparative luxury of exile. This guill was compounded when he discovered that Ken Saro-Wiwa had yet again been abducted by the 'forces of justice'.

I was beginning to recover from the gruesome 
Gecko...

... when I heard that

The armed vultures had abducted you again... ${ }^{29}$

Saro-Wiwa was one of the many victims of 'General Abacha Shells and his henchpeople $^{30}$. Mapanje recognised that Saro-Wiwa was a sacrifice to the 'biltong-dry Commonwealth', represented by multinational petroleum companies such as Shell. ${ }^{31}$ These companies economically controlled both the culture and the corruption of the peoples in South East Nigeria. When the 'henchpeople' become 'henchshells' we understand Mapanje's recognition of the perpetuation of the colonial life-style long after the demise of legislated colonisation. Suddenly oral metaphor has assumed a new identity; cowrie-shells, the traditional currency of exchange in West Africa, have become 'henchshells'. Murder has become the commodity of exchange.

...Abacha Shells' henchpersons

unleash their leeches to suck the blood

of the vociferous placarders.

Mapanje's response to Sar,-Wiwa's 'judicial murder' allows us the knowledge that acceptance of commercial expediency can never revoke indigenous identity.

The loss of Saro-Wiwa confirmed for Mapanje that more was at stake than the voice of political dissidence. He recognised the interaction between politics and poetry. Where he had once believed poetry to be the sacrosanct inheritor of the oral and indigenous creation, he now accepts that it must move forward and become a proactive voice for change.

He encapsulates this change from metaphor to pragmatism in his refrains to the three poems 'On His Life Excellency's House Arrest','Once Upon a Village' and'Beginning Where We Left Off'. The pragmatism of the first statement, 'Let others die so we can eat the (funeral) rice', transfers the exhortation to the individual or group of individuals who can be manipulated into killing for the sake of the funeral rice. But in 'Beginning Where We Left Off' what was originally a passive voice, passing responsibility to others, is now an imperative voice, 'Kill another for you to eat the funeral rice.' This stridency is the result of a post-Banda era, but it is short-lived. Mapanje advocates:

So now that the senile lion has accidentally fallen

In the chasm of his own digging, let us thank the Lord

And resume the true fight we abandoned years ago. 
Banda, 'the monster', has 'pulped his own cubs / Leaving the village tainted in sweat, tears \& blood' ${ }^{32}$. In 'The Lies We Told About the Elephant' Mapanje exposes the misuse of metaphor as myth. When Banda is seen as the elephant, this is 'another lie'.

...do not tell the children

Another lie, how wise elephant returned

To his kraal at his own fancy... ${ }^{33}$

When Mapanje exposes the equation of Banda with the elephant, he is calling upon the irony that he has previously posited. The elephant has always been the motif of memory but now this metaphor has been replaced by the reality of 'lap-tops / Faxes, diplomatic bags'. Padraig O'Maille, in his book Living Dangerously, documents the importance of the fax machine: "it revolutionised the potential for communication with the outside world it made possible the rapid exchange of information on a scale impossible heretofore' ${ }^{34}$ These corporate metaphors masque the central metaphors (the chiten$j e$, dance and chameleon) featured in Mapanje's earlier volumes. Though the symbols and lexicon have changed, the concept of metaphor remains constant. Mapanje consolidates African tradition with Western reality. ${ }^{35}$ The accepted hospitality of the African (referred to in 'Song of Chickens') is contrasted with the responsible reactions of the Western consumer. Mapanje is now denied 'total innocence'.

.... Oh time, how

Could you be so callous as to sever memories

So precious when all he desires is to redress

The anguish of nipping her pumpkin leaves $!^{36}$

This is Mapanje's reconciliation with the demands of a European literary formula and his distress at the 'callous' severance of the memories: '...for arrest is arrest: / Dehumanising, abominable, shaming, vile, et cetera' ${ }^{37}$. Whether arrest is incarceration or stoppage, the 'et cetera' reminds us that a single voice is of no importance unless it can promote itself through international print.

Mapanje has made the transition from the oral to the written tradition. While conceding the demands of his role as a pre-eminent African author he has exhibited the control of language and lyric demanded of the Western author. He has presented a body of work which gradually moves via changing metaphorical structures; in Of Chameleons and Gods he concentrated on the validation and furtherance of the voice of the praise singer; in The Chattering Wagtails of Mikuyu Prison he explored the possibilities of 
using that same voice to identify and condemn the abuse of a culture which was invading its own symbolism; in Skipping Without Ropes he accepts the maturity of an African writer who is no longer confined by his African roots. He is now able to extend the honesty of his writing to encompass the 'chattering wagtails' of all traditions. In the dedication to Skipping Without Ropes he admits, ' I thought I would offer you more muscular / Lines to help you reach the summits of this / Wandering seclusion without the tether...'. The 'tether' can be seen as the rope; but the rope is both the tool of oppression and the tool of release.
Brethren, golden glories are hard to police
But do not ask us to forget the past, and how
Could poetry forget the past when Africa still
Bleeds from forgetting its past; empower others
To forget your past - my struggle continues ${ }^{38}$

The testimony of Mapanje's work is his ability to avoid wallowing in the past while recognising and saluting its value. It is the past of myth, legend and fable, willed through an oral tradition which ultimately Mapanje has shown can be adapted to accommodate the more formal requirements of a European tradition.

Ever before this young nation should not be

Allowed to wallow in the past, the exigencies

Of building this glowing nation must precede

Everything.... ${ }^{39}$

Mapanje's three volumes approximate three stages in the conversion of the oral, indigenous language to the written English language form of poetry. This transition has necessitated a complex set of equations. Oral storytelling in a traditional language, using archetypal metaphor, becomes myth. Ideally this would be transposed into a written version using the same indigenous language and therefore the same metaphorical vocabulary. In the third stage of transition, the written version would be translated into the English language using a strict transposition of traditional metaphor. And in the final stage the written language would be English and the metaphors would have been transposed to those of a European context. Hence the evolution of the indictment to eat the funeral rice. Though Mapanje's published poetry bypassed the second stage, because he was not writing in his indigenous language, his development through the three volumes does represent this evolution of form and lexicon. Writing now at the fourth stage in the English language and with Western metaphor he could be seen as an 
inheritor of Western literary tradition as opposed to African. However, he has provided his readers with a body of verse which is his attempt to make sense of this transition.

Mapanje does not subscribe to the Western tradition at the expense of severing his own cultural roots. The very act of striving to synthesise a newly acquired 'writerly' practice with an inherited oral tradition is what succeeds in ushering the reader into Mapanje's 'fourth world': African writing in English. 


\section{Notes}

1. 'Song of Chickens', Of Chameleons and Gods, p. 4.

2. Mapanje, (unpublished M.Phil thesis, 1974)'The Use of Traditional Literary Forms in Modern Malawian Writing in English', p.18.

3. The translation 'wise old elephant' was afforded by a member of Heinemann who had spent 10 years in Kenya.

4. Swahili proverb quoted by Wilentz, Binding Cultures, p.116.

5. See 'The Lies We Told The Elephant', Skipping Without Ropes, p.70

6. The New Princeton Encyclopedia of Poetry and Poetics, ed., Alex Preminger and T.V.F. Brogan (1993), p.760.

7. See Abodunrin's article 'Black Literature and Literary Theory', Wasafiri, 1991, p.8.

8. Soyinka, Wole, Yoruba Poetry and Music, Okuta Percussion, D. 'The Animal World' (Bayreuth 1992).

9. The Old English Dictionary Volume VIII, (Oxford 1989) p.1025.

10. The Concise Oxford Dictionary of Current English, adapted by HW Fowler and FG Fowler, (Oxford 1934) p.156.

11. Mapanje, M.Phil thesis, p.30.

12. Chirambo, "Protesting Politics of 'Death and Darkness' in Malawi", p.205

13. Schoffeleers and Roscoe, p.19.

14. 'Steve Biko is Dead', Of Chameleons and Gods, p.65.

15. Information recorded in an interview with Lt. Colonel Burgess (former senior police officer 1958-69).

16. Lwanda, Kamuzu Banda of Malawi, p.7.

17. 'Another Clan of Road-fated Shrews', Skipping Without Ropes, p.28.

18. 'On Being Asked to Write a Poem for 1979', Of Chameleons and Gods, p.74.

19.Schoffeleers and Roscoe, p.225.

20. 'The Chattering Wagtails of Mikuyu Prison', The Chattering Wagtails of Mikuyu Prison, (hereafter referred to as Wagtails), p.49.

21. 'Your Tears Still Burn at My Handcuffs', p.78

22. 'The Viper Who Minutes His Own Twitches', Skipping Without Ropes, p.29.

23. Skipping Without Ropes.

24. 'The Streak-Tease at Mikuyu Prison, 25 September 1987', Wagtails, p.45.

25. Encounters from Africa, anonymous, (Nairobi 2000), p.1.

26. Ibid.

27. 'Parable of My Renault 4 Driver', Skipping Without Ropes, p. 34.

28. 'While post-colonial literary theory has drawn on European theoretical systems it has done so cautiously and eclectically.' The Empire Writes Back, p.33.

29. 'Warm Thoughts for Ken Saro-Wiwa', Skipping Without Ropes, p.46. 
30. 'Reply to Ken Saro-Wiwa's Letter', Skipping Without Ropes, p.47.

31. Abodunrin's, 'Oratory in the Tongue:...', pp.43-60.

32. 'Beginning Where We Left Off', Skipping Without Ropes., p.61.

33. 'The Lies We Told About the Elephant', Skipping Without Ropes, p.70.

34. O' Maille, Living Dangerously, p.126.

35. See 'Guilty of Nipping Her Pumpkin Leaves', Skipping Without Ropes, pp.66-7. 36. Skipping Without Ropes, p.66.

37. 'On His Life Excellency's House Arrest', Skipping Without Ropes, p.59.

38. 'When the watery monsters argued', Skipping Without Ropes, p.73.

39. Skipping Without Ropes. 


\section{References}

Abodunrin, F. 1991. Black Literatures \& Literary Theory. Wasafiri, 14. .2001. Oratory in the Tongue: Ken Saro-Wiwa's A Month and a Day and the writer in Politics. The Journal of Humanities, 15.

Ashcroft, B. et al., 1989. The Empire Writes Back: Theory and Practice in Postcolonial Literatures. London \& New York: Routledge.

Chirambo, R. 2001. Protesting Politics of 'Death and Darkness' in Malawi. Journal of Folklore Research, 38, 3.

Dubbey, J. 1994. Warm Hearts White Hopes. Penrose Books: Gaberone.

Elimimian, I.I. 1991. Theme and Style In African Poetry. New York: Lampeter.

Gill, R. 1974. William Empson; the man and his work. London: Routledge \& Kegan Paul.

Gordimer, N. 1999. Living in Hope and History. London: Farra Straus \& Giroux.

Grey, S. ed. 2000. The Picador Book of African Stories. London: Picador.

Hawkes, T. (gen. ed. 1989. The Empire Writes Back. London: Routledge.

Lwanda, J.L. 1993. Kamuzu Banda of Malawi: A Study in Promise, Power and Paralysis. Glasgow: Dudu Nsomba.

Lwanda, J.L.1996. Promises, Power, Politics \& Poverty Democratic Transition in Malawi (1961-1999). Glasgow: Dudu Nsomba.

Letts, J. and F. Whytehead, ed. 1999. Captured Voices. London: Indigo. Macmillan Kenya, ed. 2000. Encounters from Africa. Nairobi.

McCracken, J. 2000. Politics \& Christianity in Malawi 1875-1940. Cambridge: Cambridge University Press.

Mapanje, J. 1981. Of Chameleons and Gods, Oxford: Heinemann. 1998. Skipping Without Ropes. Newcastle upon Tyne: Bloodaxe Books. 1993. The Chattering Wagtails of Mikuyu Prison. Oxford: Heinemann. and White L. 1983. Oral Poetry from Africa. Harlow: Longman.

Markham, E.A. ed. 1989. Hinterland; Carribbean Poetry from the West Indies \& Britain. Newcastle upon Tyne: Bloodaxe Books.

O’ Maille, P. 1999. Living Dangerously. Glasgow: Dudu Nsomba.

Ngara, E. 1990. Ideology and Form in African Poetry. London: James Currey. Roscoe, A. \& Msiska, M.H. 1992. The Quiet Chameleon. London: Hans Zell. Rubadiri, D. 1967. No bride price. Nairobi: East Africa Pub. House.

Schoffeleers, J.M. and Roscoe A.A. 1985. Land Of Fire: Oral Literature from Malawi. Limbe: Montfort Press.

Vail, L. \& White, L. 1991. Power and the Praise Poem. Charlottesville: University Press of Virginia.

Wilentz, G. 1992. Binding Cultures. Indianapolis: Indiana University Press. 
Williams, T.D. 1978. Malawi: The Politics of Despair. London: Cornell University Press.

Young, C. and Banda, H. 1946. Our African Way Of Life. London \& Redhill: Luterworth.

Juniper Cottage

Glen Road

Grayshott

Surrey GV26 6NE

United Kingdom.

akmcfarlane@hotmail.com 